\title{
IAMJ
}

INTERNATIONAL

AYURVEDIC

MEDICAL JOURNAL

\section{CONCEPT OF MEDODHATU WITH ITS PHYSIOLOGICAL IMPORTANCE W.S.R. TO LIPIDS}

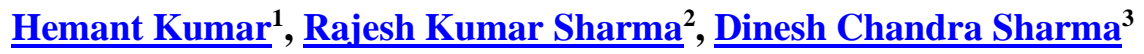 \\ ${ }^{1}$ P.G. Scholar, ${ }^{2}$ Professor and H.O.D., ${ }^{3}$ Associate Professor, \\ P.G. Department of Kriya Sharir, DSRRAU, Jodhpur, Rajasthan, India
}

Corresponding Author:hemantgarghunny@gmail.com

https://doi.org/10.46607/iamj2909092021

(Published Online: September 2021)

Open Access

(C) International Ayurvedic Medical Journal, India 2021

Article Received:14/08//2021 - Peer Reviewed:30/08/2021 - Accepted for Publication:31/08/2021

\section{Check for updates}

\section{ABSTRACT}

In Ayurvedic classical texts, Sama Dosha, Sama Dhatu and Sama Mala, Samaagni, and Prasanna Mana are indicated signs of Swasthya. Among these Sama Dhatu is a major factor for healthy status of any person. Dhatus are responsible for Dharana and Poshana of the body in their healthy state and when vitiated they also act as Dushya and hence vitiate and disturb the equilibrium of the body. There are 7 seven Dhatus in the body and among these $4^{\text {th }}$ Dhatu is Medodhatu. Medodhatu can be correlated with lipids in modern perspectives. This article is an attempt to give a detailed description of Medodhatu and lipids and to understand their importance in the body.

Keywords: Dhatu, Meda, Dharana, Medodushti, Lipids etc.

\section{INTRODUCTION}

The physiology of the human body depends upon the equilibrium of Dosha, Dhatu and Mala. Doshas can be stated as the main bio energies of the body and are responsible for all physiological functions. The activities are executed through Dhatu and Malas and hence act as media. In these media, Dhatus are the 
stabilising pillar of the body whereas Malas are excretory byproducts that are formed due to different metabolic activities of the body. According to Ayurveda, the human body is built of Seven Dhatus or body elements and Meda Dhatu is the $4^{\text {th }}$ Dhatu among those. Medodushti is a Dushya dominant disorder and hence Medo Dhatu is important in the development of pathogenesis of Medodushti. To understand the pathology related to Medo Dhatu, understanding physiology is mandatory, so, physiological aspects of principle Dushya i.e., Medo Dhatu is detailed.

\section{MATERIAL AND METHODS}

The materials were collected from the classical Ayurvedic literature, magazines and research journals.

\section{CONCEPT OF MEDO DHATU NIRUKTI OF MEDA-}

The word Meda is derived from Sanskrit word 'Mid' with the addition of 'Asun' and 'Ach' Pratayay respectively.

- Meda is specific Dhatu which is originated from Mamsa and Vapa and Vasa are synonyms to it.

- Meda signifies corpulence and is a synonym for Vapa and Vasa.

Medas- fat, marrow, fat of body (san-Englishdictionary)

\section{SYNONYMS-}

Asthikruta- Next Dhatu after Meda is Asthi (Bone) and Meda Dhatu acts as a substrate for the formation of AsthiDhatu.

Mamsaj and Mamsateja- As, with the action of Mamsadhatwaagni, it is formed from Mamsa Dhatu. STHAN AND SWARUPA OF MEDO DHATU ${ }^{I}$ Medo Dhatu is Sneha dominant Drava Dhatu and having Guru (heavy), and Snigdha (oiliness) properties.

Anatomically, Meda is a yellowish, greasy, soft, solid material known as fat. A countless number of globules of fat form a thick, spongy layer under the skin.

ANJALI PRAMANA OF MEDO DHATU ${ }^{2}$

The quantity of Meda according to ancient Acharyas is 2 Anjali and Praman of Vasa is 3 anjali. The Anjali praman may have variation from person to person. Thus, total Medas content adding Medo Dhatu, and Vasa is 5 anjali. If we add total Anjali Pramanas of all elements are counted as 56.5 Anjali; hence the proportion of Medas in the body element is $1 / 11$ of total body weight. This number is important as modern science also tells that the total fat content of the body is $1 / 12$ of total body weight.

\section{PROPERTIES AND PANCHBHAUTIC COMPOSITION OF MEDODHATU ${ }^{3}$ -}

Meda Dhatu is sneha dominant Drava Dhatu, (sneha is Guru and Snigdhagunayukta, Teja and Bhrajishnutayukta, dominated by Jalamahabhuta). Prithvi, Apa and Teja Mahabhutas are dominant constituents of Meda Dhatu.

TYPES OF MEDO DHATU ${ }^{4}$ :

To understand Medo Dhatu from a modern perspective, it can be said that there are 2 types of MedoDhatu-

\section{Baddha Meda or Poshya Medo Dhatu.}

2. Abaddha Meda or Poshaka Medo Dhatu.

\section{Poshya / Baddha Medo Dhatu-}

Poshya Medo Dhatu is stored in Medodharakala. It is immobile in nature (Gativivarjita). Udara and Anuasthi are sites of Medodhaarakala. Other sites like Sphikka, Stana and Gala are also depots of Poshya Meda.

\section{Poshaka/ Abaddha Meda Dhatu-}

Poshaka Medo Dhatu is mobile (gatiyukta) and circulated with Rasa-Rakta Dhatu in the whole body to provide nutrition to Poshya MedoDhatu. Circulating lipids along with cholesterol within the blood can be visualised by different imaging techniques.

After Mamsagnipaka, this Poshaka MedoDhatu is distinguished in the form of Sukshmabhaga \& Sthulabhaga and then further transformation of MedoDhatu occurs by this.

\section{UTPATTI OF MEDO DHATU}

Origin of Medo Dhatu is from Prasadbhaga of Mamsa Dhatu.

When poshak mamsa Dhatu is acted by mamsagni, it is then divided into three parts due to mamsagni paka- 
1) Sthulabhaga- This part is responsible for sthayi mamsa Dhatu.

2) Sukshamabhaga- This part is responsible for the further formation of Medo Dhatu.

3) Kittabhaga- Also known as khamala (waste of openings) of body.

Here Medodhatwagni acts upon Sukshmabhaga (poshaka Medo Dhatu) and Poshaka Medo Dhatu is then converted into sthulabhaga (Shtayi /poshya Medo Dhatu), Sweda (Malabhaga) and Poshaka Asthi Dhatu as a Sukhsma Bhaga. The processes of nourishment of Medo Dhatu by Annarasa keep running in this manner.

Acharya Charak mentioned that the nutrients of Medo Dhatu present in Mamsa Dhatu are converted into Medo Dhatu when these nutrients combine with Apa mahabhuta during paka which makes Dhatu snigdha and drava.

\section{KARMA OF MEDO DHATU-}

Different Acharyas mentioned the function of Medo Dhatu as ${ }^{5}$ -

\section{1) Snehana-}

Lustre of skin, hair and eyes depends upon Sneha quality of Meda. In Medovridhhi or Medoroga, the Snigdhagatrata arises which may be due to Snehana function of Meda.

2) Sweda ${ }^{6}$ -

Sweda is mala of Medo Dhatu. Acharya Sharangdhara listed Sweda as Upadhatu of meda.

\section{3) Asthipushti-}

Nourishment of further Dhatu i.e., Asthi Dhatu is also a function of Medo Dhatu. Nourishment of its snayu upadhatu, (and Sandhi acc. to Chakrapani), is another function of medodhatu.

\section{4) Dridhatva-}

Dridhatva or strength is provided by snayu upadhatu of meda. Snayu provides strength to the Asthi and Sandhi. Meda also provides strength to abdominal organs. It helps in the bindings of important organs. Layers of fatty tissue depots over the underlying organ present in the abdomen protect from outside pressure and frictions. Dridhatva is also taken as energy as meda is an energy store of the body and provides almost double energy compared to carbohydrates and proteins.

\section{5) Netra and Gatrasnigdhta-}

Both are a symptom of Sthaulya and may produce due to increase Snehana function of Meda.

\section{UPADHATU OF MEDA ${ }^{7}$}

According to Acharya Charak snayu is Upadhatu of Meda.In Vaidhyaka Shabda Sindhu, Snayus is the Nadi that conducts vayu. Vayu conducts the Sneha of Meda and make the Sira, and Snayu. Snayu provides strength to the body by binding Mamsa (muscles), Asthi (bones), Meda (adipose tissue) and strengthening the joints.

The body is stable and sturdy because of snayu.

\section{MALA OF MEDA ${ }^{8}$ -}

Sweda is mala of meda.

\section{MEDODHARA KALA-}

Kala refers to the fine structures separating the Dhatus from there Ashaya $a^{9}$. Medodhara kala is $3^{\text {rd }}$ kala in the body. The function of Medo Dhatu is to support Medo Dhatu ${ }^{\mathbf{1 0}}$. An interesting and farreaching statement made by Acharya Sushruta that, the meda that fills up the shaft of long bones is known as majja and that which is present in the small bones (anuasthi) is called sarkta meda i.e., blood cum fat ${ }^{11}$.

\section{MEDOVAHA SROTAS ${ }^{12}$ -}

The channels present in the body through which Poshaka Dhatu, and Mala pass to and from the Sthayi Poshya Dhatu are called Srotas. According to Acharya Charak, "nutrient substances which nourish the Dhatu undergo Paka by the Ushma of Dhatu (Dhatwagni) and then only they made available to the Dhatu through their Srotasa.

Medovah srotas can be explained as the Srotas carrying the nutritive material up to the site of Medo Dhatu or the channels which give nutrition to the Medo Dhatu. The channels which are related to the transport of adipose tissue are considered as Medovah srotasa as explained by C. Dwarkanath ${ }^{13}$.

The capillaries of the peripheral tissue and omentum are to be considered medovah srotas according to $\mathrm{Dr}$ Ghanekar BG. ${ }^{14}$ 
A network of capillaries or blood vessels holds the fat cells together distributed them to them. ${ }^{15}$ Hence the channels through which the Poshaka or Asthayi Medo Dhatu circulated in the whole body in mixed form with Rasa and Rakta, to nourish the Sthayi or poshya Medo Dhatuare called Medovah Srotas. In case of defect or vitiation of Medovah Srotas, Medodushti or Medoroga takes place.

\section{Moola of Medovah Srotas}

According to Brihatrayee-

Charak-Vrikka and Vapavahana ${ }^{\mathbf{1 6}}$

Sushruta- Vrikka and Kati ${ }^{17}$

Vagbhatta- Vrikka and Mamsa ${ }^{18}$

The word moola means origin. The medovaha srotas moola means the organs which are the origin of Medo Dhatu. Moola can be understood as the organs which are closely related to the functions of MedoDhatu, or important sites related to the beginning or end of the channels of Medo Dhatu.

Hence according to all the three Acharyas, vrikka is one of medovaha srotas. It seems that all Acharyas are known to the importance of vrikka physiologically and anatomically. But Acharya Sushruta and Acharya Vagbhatta mentioned kati and mamsa as the second moola of medovah sortas which seems less physiologically and more anatomically correct as compared to vapavahan which is mentioned by Acharya Charak as the second moola of medovahsrotas.

\section{VRIKKA}

Vrikka is formed from Sara part of Rakta(blood) and Meda (fat). Its function is to nourish the meda. The situation of vrikka, which are 2 in number, is in both the side of the mid vertebral line inside the abdominal cavity. According to Acharya Sharangdhara, vrikka nourishes the medo Dhatu inside the stomach area of the abdominal cavity ${ }^{19}$ while Acharya Charak mentioned them as Moola of Medovah Srotas. Acharya Sushruta and Vagabhatta also mentioned Vrikka as the Moola of Medovah srotas and also placed at the primary position. There is no clear evidence of kidneys taking part in fat metabolism both according to modern science and Ayurveda. But if suprarenal glands, which are present just above the kidney attached to it, and function in the body in the metabolism of fat by its secretions, the perspective of Acharyas can be correctly established with correct relation according to modern science. Hence vrikka (kidney) with suprarenal glands are Moola of Medovah Srotas.

\section{VAPAVAHAN}

Acharya Chakrapani also accepted the viewpoint of Acharya Charak of Vapavahan as the place of meda. It is also known as Taila vartika. ${ }^{\mathbf{2 0}}$ Dr.Ghanekar explained it as the place where maximum meda is stored. ${ }^{21}$ The situation of vapavahan is beneath the Jathare (stomach) and beyond Pleeha (spleen). Kloma is also used as the synonym of vapavahan. Kloma in ayurvedic science is not clearly defined. But it is included in kosthanga according to Acharya Charak. So, based on this fact, if pancreas is kloma, which is very important for digestion and metabolism of fat, the vapavahan can be called the moola of medovaha srotas. Physiologically the fact fits in both Ayurveda and Modern science's perspective.

\section{KATI}

Kati is the place where generally the fat accumulates. Kati is mentioned as Moola by Acharya Sushruta. Anatomically kati has a big amount of fat around it, and in patients with obesity, it is vast in quantity. This may be the reason why Acharya Sushruta mentioned kati as the Medovaha srotas moola.

\section{MAMSA}

The layer of fat under the skin is closely related to the muscles. Mamsa as Medovah srotasmoola can be correlated with the vasa (mamsagata sneha) below the skin. That's why Acharya Vagabhatta considered Mamsa as Mola of Medovah srotas.

\section{MEDASARA PURUSHA ${ }^{22}$ -}

Physical characters-

- Lustre of the skin

- Deepness invoice

- Glittering eyes

- Shiny hairs and nails

- Unctuous and moist lips

- Shiny teeth

- Oily urine

- Oily faeces 
Behavioural and Psychological characters-

- Medasara purusha is blessed with wealth,

- Dignity in society

- Happiness

- Luxury

- Righteousness

- Generosity

- Delicacy

\section{DIFFERENCES BETWEEN MEDA, MAJJA} AND VASA

MEDA-Meda is the sneha part present in form of a compound in the body. This meda is mainly present in the structure of the cell and other structures in compound form and mainly in phospholipids and sterols. It cannot be separated from the cell as it is the structural element of the cell and its removal from the cell ultimately leads to the death of the cell. Hence this sneha is not available to the body for use.

MAJJA-Acharya Charak had mentioned detailed information about the formation of Majja Dhatu. Acharya said that the formation of Majja Dhatu is from Asthi Dhatu. The Snigdhamsa of Medo Dhatu fills the hollow spaces created by Vayu Mahabhuta in long bones which are then called Majja Dhatu.

Majja and Meda both are fat tissue, but Ayurveda mentioned them as two different Dhatu. It might be due to their different specialised functions in the body. Vaidhyak Shabda Sndhu described Majja as shuddha Sneha (pure fat). The composition which is said to be Shuddha sneha of Majja is similar to the fat stores in the adipose tissue which are present everywhere in the body like sterarin and olein.

Kaviraj Gananath sen explained 2 kind of majja

1) Rakta 2) Peeta.

Peeta majja is found in Nalakasthi and Raktamajja is found in all other long bones.

VASA-Vasa are Mamsa Dhatu's Upadhatu. Vasa is mainly oily substances derived from Mamsa Dhatu.Vasa is indicated for persons debilitated after heavy work, walking and exertion, indulged in excessive sexual intercourse, anaemic patients and for patients suffering from the disease of bone, joints, blood vessels, ligaments. Vasa upadhatu improves complexion and maintains the shape of the body.
According to modern sciences, vasais neutral fat stored in the body and named adipose tissue. It is liquid in living conditions and takes solid form after death.

It helps in the maintenance of body temperature (homeostasis) because it is a bad conductor of heat. It is present in maximum quantity in muscles, subcutaneous tissue, and abdomen. Cells of subcutaneous tissues have Vasa in place of protoplasm, but Vasa is Upadhatu and its functions are only Dharan and not Poshana. Hence it can be taken outside from the cell.

Sneha is present in compound form in meda, in mixture form in Majja and pure form in vasa.

\section{CONCEPT OF LIPID}

'Lipids' word is derived from the Greek word lipos which mean fat. Lipids are the chief concentrated storage form of energy, and hence definitely are of great importance to the body.

They have also a role in cellular structure and various biochemical functions. It is difficult to define them precisely as lipids are heterogeneous groups of compounds. The organic substances are soluble in organic solvents (like alcohol, ether etc.) but insoluble in water, and potentially related to fatty acids and utilized by living cells. Lipids are a major form of stored nutrients (TGs), precursor of gonadal and adrenal steroids and bile acids (cholesterol) and messengers like prostaglandins which act intracellular and extracellularly are also made of lipids. Complex lipids in the blood are delivered to cells throughout the body as water-soluble complexes by lipoproteins.

Physiologically lipids present in the body form 2 components-

\section{Structural lipids or element constant-}

In the entire organ of the body, cytoplasm and cell membrane are composed of element constant. So that in case of starvation, the fat content of cytoplasm and cell membrane does not diminish. Element constant is chiefly composed of phospholipids and the value of it always remains constant. 


\section{Element variable-}

Chiefly neutral fats are its components. The depots of fat (adipose tissues) are the sites where they are present in free form and represent stored energy. Depot fats are not static but due to their continuous synthesis and breakdown in the body, they remain in a continuous state of change.

\section{- Classification of lipids}

Lipids are classified mainly in 2 ways-

* Based on the storage and structural lipids and some other functional lipids.

* Based on lipid composition

1. Simple lipids- simple lipids are esters of fatty acids with alcohols.

a) Neutral fats: Triglycerides (TGs), ester of various fatty acids with glycerol.

b) Waxes- cholesterol and its esters.

2. Compound lipids- these are esters of fatty acids with alcohols and contains other groups.

a) Phospholipids - Esters containing phosphoric acids and a nitrogen base i.e., lecithin and cephalin.

b) Glycolipids - esters containing carbohydrate and a nitrogen base i.e., cerebrosides.

c) Sulpholipids - esters containing sulphuric acid.

d) Lipoproteins - lipids attached with proteins.

3. Derived lipids- hydrolysis of simple and compound lipids results in derivative formation and they still process the physical characteristics of lipids. They are divided as-

a) Fatty acid- saturated and unsaturated

b) Sterols

c) Fat-soluble vitamins

\section{- Functions of lipids-}

Unlike carbohydrates which are heavily hydrated to perform a wide variety of functions, lipids are stored in a relatively water-free state in the tissue.

Lipids perform several important functions-

1) Energy store - Lipids are the concentrated fuel store of the body (triglycerides).

2) Regulates membrane permeability- Lipids are constituents of membrane structure and regulates the membrane permeability (phospholipids and cholesterol)
3) Source for vitamins - they serve as a source for fat-soluble vitamins (Vit. A, D, E, K.)

4) Metabolism regulation - Lipids are important as cellular metabolic regulators.

5) Protective functions - lipid protects the internal organs by serving as a cushion to absorb shock.

6) The appearance of the body - lipid provides shape and a smooth appearance to the body.

7) Insulating function - the subcutaneous lipids serve as insulating materials against heat and cold from the atmosphere.

8) Electron transport chain - lipid present in inner mitochondrial membrane actively participate in the electron transport chain.

\section{Lipid transport in the body- ${ }^{23}$}

Triglycerides, cholesterol, and phospholipids are transported in the form of lipoproteins in the plasma. These lipoproteins have apoproteins, which is a protein component. Examples of apoproteins are- AI, A-II, C, E, B-48 and B-100. There are mainly 2 ways for transport of lipids.

\section{1) Exogenous pathway}

2) Endogenous pathway

1) Exogenous pathway-

The exogenous pathway is credible for dietary fat's digestion and tissue dissemination. This transport is done through chylomicrons. Chylomicrons are the water-soluble micelles that are formed when interstitial cells or enterocytes takes up the dietary triglycerides and $50 \%$ of cholesterol after combination with bile salts. These chylomicrons then secreted intestinal lymphatic, and via the thoracic duct, they reach to blood. Apo CII/III is incorporated by them. The lipoprotein lipase enzyme which is present in the endothelial surface of capillary beds in cardiac muscle, skeletal muscle and adipose tissue, removes the TG component. Free fatty acids and glycerols are formed from the catalysis of triglycerides which is done by lipoprotein lipase. In the fat cells of adipose tissues and muscles, these free fatty acids and glycerols diffuse freely. Here Precursor of HDL is formed after the shed of apolipoproteins and phospholipids and the remaining cholesterol is taken up by the hepatic LDL receptor 
and to be used to produce VLDL and bile acid and some are excreted into the bile.

\section{2) Endogenous pathway}

The endogenous pathway transports lipids from peripheral tissue to the liver and from the liver to peripheral tissue. It is classified into two subsystems.

i) The ApoB-100 lipoprotein system: in this transport of cholesterol, triglycerides, phospholipids etc. is done from the liver to other tissues through VLDL and LDL ii) The ApoA-I lipoprotein system: in this transport of reverse cholesterol through HDL from other tissues to the liver.

\section{Depot fats-}

Plasma proteins and fat depots are two forms in which fat is present in the body. Fat makes about $12 \%$ of the total weight of the body. A maximum part of this fat remains stored. These fat storages are called fat depots.

Table 1: Showing fat distribution in the body tissue-

\begin{tabular}{|l|l|}
\hline Body tissue & Fat distribution in \%age \\
\hline Subcutaneous tissue & 50 \\
\hline Peripheral tissue & 15 \\
\hline Mesentery & 20 \\
\hline Omentum & 10 \\
\hline Intramuscular connective tissue & 9 \\
\hline
\end{tabular}

\section{Composition of depot fats}

These are consisting mainly of mixed triglycerides with some amount of cholesterol, lecithin, and polyunsaturated fatty acids.

\section{Functions of depot fats-}

1. physical- regulation of body temperature (thermostatic)

2. mechanical- it protects against injury

3. chemical- storages of energy $(1100 \mathrm{cal} / \mathrm{kg}$ body weight)

\section{Storages of fat-}

Large quantities of fats are stored in two major tissues in the body-

- adipose tissue

- liver

\section{Adipose tissue-}

Adipose tissue makes about 20 per cent of a normal young adult's total body weight. In an average person, it is about $15 \mathrm{~kg}$. This storage can be increased to no limits. If the body mass increases, it represents the enlargement of the adipose tissues. Approximately 90 per cent of the adipose tissue's mass represents stored triglycerides.

\section{Liver}

In conditions like starvation, diabetes mellitus and any other such condition, a large number of triglycerides appears in the liver. Mobilisation of most of the triglycerides occurs as free fatty acids from the adipose tissue in the blood and then redeposition occurs as triglycerides in the liver.

\section{CONCLUSION}

Meda dhatu is an important part of the body and performs many functions and maintains the homeostasis of the body. According to both Ayurveda and modern point of view, there are many similarities between medodhatu, and lipids as discussed in this article. These similarities also show the importance of medodhatu in the body.

\section{REFERENCES}

1. Kashinath Pandey And Gorakhnath Chaturvedi Charaksamhita Vidyotinivyakhya Part -II Chikitsa Sthan 15/30, Reprint 2009 Varanasi Chaukambha Bharti Academy

2. Kashinath Pandey And Gorakhnath Chaturvedi Charaksamhita Vidyotinivyakhya Part -I sharirSthan 7/15, Reprint 2009 Varanasi Chaukambha Bharti Academy 
3. Kashinath Pandey And Gorakhnath Chaturvedi Charaksamhita Vidyotinivyakhya Part -II Chikitsa Sthan 15/27-32, Reprint 2009 Varanasi Chaukambha Bharti Academy

4. Kashinath Pandey And Gorakhnath Chaturvedi Charaksamhita Vidyotinivyakhya Part -I nidana Sthan 4/7, Reprint 2009 Varanasi Chaukambha Bharti Academy

5. Kashinath Pandey And Gorakhnath Chaturvedi Charaksamhita Vidyotinivyakhya Part -II ChikitsaSthan 15/17, Reprint 2009 Varanasi Chaukambha Bharti Academy

6. Kashinath Pandey And Gorakhnath Chaturvedi Charaksamhita Vidyotinivyakhya Part -II ChikitsaSthan 15/18, Reprint 2009 Varanasi Chaukambha Bharti Academy

7. Kashinath Pandey And Gorakhnath Chaturvedi Charaksamhita Vidyotinivyakhya Part -II ChikitsaSthan 15/17, Reprint 2009 Varanasi Chaukambha Bharti Academy

8. Kashinath Pandey And Gorakhnath Chaturvedi CharaksamhitaVidyotinivyakhya Part -II ChikitsaSthan 15/18, Reprint 2009 Varanasi Chaukambha Bharti Academy

9. Ambikadutta shastri, Sushrutsamhita Ayurvedtatvasandipika Part-I Shareersthana 4/5 Varanasi Chaukambha Sanskrit Sansthan.

10. Ambikadutta shastri, Sushrutsamhita Ayurvedtatvasandipika Part-I Shareersthana 4/12 Varanasi Chaukambha Sanskrit Sansthan.

11. Ambikadutta shastri, Sushrutsamhita Ayurvedtatvasandipika Part-I Shareersthana 4/13 Varanasi Chaukambha Sanskrit Sansthan.

12. . Kashinath Pandey And Gorakhnath Chaturvedi Charaksamhita Vidyotinivyakhya Part-II vimanaSthan 5/3-6, Reprint 2009 Varanasi Chaukambha Bharti Academy

13. . Introduction To KC, C. Dwarkanath, Chapter 21, Page No. 375.

14. Ghanekar Commentary On Sushruta Samhita 9/18

15. Grey's Anatomy Page No. 10.

16. Kashinath Pandey And Gorakhnath Chaturvedi Charaksamhita Vidyotinivyakhya Part-II vimanaSthan 5/7, Reprint 2009 Varanasi Chaukambha Bharti Academy

17. Ambikadutta shastri, Sushrutsamhita Ayurvedtatvasandipika Part-I Shareersthana 1/12 Varanasi Chaukambha Sanskrit Sansthan.
18. Kashinath Pandey And Gorakhnath Chaturvedi Charaksamhita Vidyotinivyakhya Part-II vimanaSthan 6/18, Reprint 2009 Varanasi Chaukambha Bharti Academy

19. Dr Smt. Shailjashrivastav, sharangdharasamhita, jeevanpradasvimarsha Hindi vyakhya, purvakhand $5 / 47$, 4th edition 2005, chaukhambhaorientalia, Varanasi.

20. Kashinath Pandey and Gorakhnath Chaturvedi Charaksamhita Vidyotinivyakhya Part -I ShareerSthan 3/6, Varanasi Reprint 2009, Chaukambha Bharti Academy, Charak Samhita Sareersthan 3/6 Chakrapani tika.

21. Ghanekar Commentary OnSushruta Samhita 4/13

22. Kashinath Pandey And Gorakhnath Chaturvedi Charaksamhita Vidyotinivyakhya Part -II vimanaSthan 8/106, Reprint 2009 Varanasi Chaukambha Bharti Academy

23. Asui, BraunealdIselbachar, Wilson, Martin, Kasher Hauser et.al., Harrison's Principle of Internal Medicine, 18h Edition, New York; McGrew - Hill, 2012, vol.2 Pg no: 2416-2428

\section{Source of Support: Nil \\ Conflict of Interest: None Declared}

How to cite this URL: Hemant Kumar et al: Concept Of Medodhatu With Its Physiological Importance W.S.R. To Lipids. International Ayurvedic Medical Journal \{online\} 2021 \{cited September 2021\} Available from: http://www.iamj.in/posts/images/upload/2113 2121.pdf 